\title{
Hematological parameters of Colossoma macropomum naturally parasitized by Anacanthorus spathulatus (Monogenea: Dactylogiridae) in fish farm in the Peruvian Amazon
}

\author{
Luis Soberon • Patrick Mathews • Antonio Malherios
}

Received: 5 October 2014 / Accepted: 6 November 2014/Published online: 19 November 2014

(C) The Author(s) 2014. This article is published with open access at Springerlink.com

\begin{abstract}
In the Peruvian Amazon, there is no information about hematological parameters of parasitized fish maintained in fish farms. In this study, the effects of parasitism by Anacanthorus spathulatus on hemoglobin $(\mathrm{Hb})$, hematocrit $(\mathrm{Ht})$, red blood cells $(\mathrm{RBC})$, mean corpuscular volume (MCV), mean corpuscular hemoglobin ( $\mathrm{MCH})$, mean corpuscular hemoglobin concentration (MCHC), glucose levels, and leucocytes were analyzed in Colossoma macropomum. The low level of parasitism found in the fish was not responsible for alterations in $\mathrm{Hb}, \mathrm{Ht}, \mathrm{RBC}, \mathrm{MCV}, \mathrm{MCH}, \mathrm{MCHC}$, and leucocytes $(0.05>p)$. However, significant increases were observed to the levels of glucose $(p<0.05)$. This is the first report regarding hematology of cultivated freshwater fish which are infected with monogeneans in the Peruvian Amazon.
\end{abstract}

Keywords Hematology $\cdot$ Teleost $\cdot$ Aquaculture $\cdot$ Parasites $\cdot$ Peruvian Amazon

\section{Introduction}

The Colossoma macropomum Cuvier, 1818 (Characiformes: Characidae), known as tambaqui or gamitana, is an endemic species of the Amazon Basin and is considered the second largest fish in South America (AraujoLima and Goulding 1997). The C. macropomum can reach up to $90 \mathrm{~cm}$ in length and $30 \mathrm{~kg}$ of total weight and is a highly appreciated species with great acceptance on the Amazonian market being regarded as an eatable fish of the highest quality (Gomes et al. 2006). However, due to its high demand as food for the population of the Amazon region, in recent years, the natural stocks of this fish have suffered drastic reduction (Santos and Santos 2005). Growing tambaqui is then a solution to the over-exploitation of this species in many rivers of the

L. Soberon

Department of Food Sciences and Hematology, Institute Research of the Peruvian Amazon, Iquitos 780, Loreto, Peru

e-mail: soberon1719@ hotmail.com

P. Mathews $(\square)$

Department of Parasitology, Institute of Biology, University of Campinas, Avenida Bertrand Russel, s/n, Campinas,

São Paulo 13083-865, Brazil

e-mail: patrickmathews83@gmail.com

A. Malherios

Department of Biological Science, University of State of Mato Grosso, Cáceres, Mato Grosso 78200-000, Brazil

e-mail: malheiros@unemat.br 
Amazon. Currently, tambaqui is the most frequently native species cultivated in the Peruvian Amazon, and moreover, the most frequent in fish farms around the country (Alcántara et al. 2003).

In fish farming, the intensive exploitation allows the handling of high densities of organisms per unit area. Indeed, this type of management frequently leads to break the balance between pathogen and host, consequently resulting in the emergence of infectious and parasitic diseases which cause various problems ranging from slow up growth, reduced fertility rates, until the appearance of severe epidemics resulting in high mortality (Scholz 1999).

The evaluation of hematological parameters could be useful for the diagnosis of diseases and to monitor the physiological and health status of fishes (Barton and Iwama 1991). Parasitism may induce lower fish growth and promote hematological alterations (Ruane et al. 2000). In the semi-intensive and intensive culture, these alterations may affect the natural resistance of fish against parasites. In the Peruvian Amazon, the ectoparasites are the main reason responsible for fish damage in intensive and semi-intensive culture (Mathews et al. 2012, 2013a, b). However, little is known about the influence of ectoparasites on the hematological parameters of fishes in fish farms in the Peruvian Amazon.

Therefore, with the gradual increase of intensive and semi-intensive fish farming in the region of the present research, there is a need for constant monitoring of the fish for the diagnosis and timely control of diseases. In the present study, the hematological parameters were evaluated in parasitized gamitana fish cultivated in cages.

\section{Materials and methods}

Between September and November 2013, which corresponds to the relative dry season, 180 individuals of the species $C$. macropomum born in captivity with mean length $16.5 \pm 1.6 \mathrm{~cm}$ and mean weight $81.20 \pm 3.22$ were obtained from a semi-intensive fish farm. The fish had been living at nine cages $\left(1.6 \mathrm{~m}^{3}\right)$ constructed with an iron frame $(1 \times 1 \times 1.2 \mathrm{~m})$, containing styrofoam blocks as floaters, and a 210/36 knotless nylon net with $15 \mathrm{~mm}$ mesh size in one earthen pond of $5,000 \mathrm{~m}^{2}$, belonging to the fish culture station Quistococha Research Center $\left(3^{\circ} 48^{\prime} 48.9^{\prime \prime} \mathrm{N}\right.$ and $\left.073^{\circ} 19^{\prime} 18.2^{\prime \prime} \mathrm{W}\right)$, located between the cities of Iquitos and Nauta, Department of Loreto, Peru.

The physicochemical parameters of the water were measured three times daily (at 8 a.m., noon, and 4 p.m.) with daily checks of dissolved oxygen, $\mathrm{pH}$, temperature, and conductivity by means of a YSI multiparameter meter (Model MPS 556). Ammonium values, hardness, carbon dioxide, and total alkalinity were monitored weekly and in the morning ( 8 a.m.), using a complete package for analysis of freshwater (LaMotte AQ-2). The fish were fed thrice daily (at 8 a.m., noon, and 4 p.m.) with extruded diet containing $25 \%$ crude protein during 90 days. The feeding rate (dry weight basis) was varied according to fish weight: $3.5 \%(10-100 \mathrm{~g}), 3 \%$ (100-200 g), and $2.5 \%$ (200 g to harvest) of the fish body weight (wet weight basis).

For hematological measurements, fish were anesthetized with benzocaine solution $\left(50 \mathrm{mg} \mathrm{L}^{-1}\right)$ and the blood samples were collected by puncture of the caudal vein of all specimens, using a syringe containing anticoagulant $10 \%$-EDTA for direct determination of red blood cells (RBC) (Celm Model CC510); leukocytes number according to Martins et al. (2004) and differential counting of leucocytes using the combination of Giemsa/May-Grünwald staining (Rosenfeld, 1947); hemoglobin (Hb) according to Collier (1944); hematocrit (Ht) according to Goldenfarb et al. (1971); and mean corpuscular volume (MCV), mean corpuscular hemoglobin $(\mathrm{MCH})$, and mean corpuscular hemoglobin concentration (MCHC) calculated according to the method proposed by Wintrobe (1934). Glucose levels were measured with a blood glucose monitor (Advantage $^{\mathrm{TM}}$ 2, Germany). Plasma was obtained through blood centrifugation at 3,500 $\mathrm{g}$ for $5 \mathrm{~min}$, and then stored at $-20{ }^{\circ} \mathrm{C}$ until analysis (Gomes et al. 2006).

After blood collection, parasitological exam consisted of scraping the body mucus and smears of organs for parasite evaluation. For examination of the gills, the samples were separated and placed in glass containers with a 1:4,000 formalin solution. After $1 \mathrm{~h}$, the gills were stirred in the liquid and then removed from the container. Helminths were allowed to settle on the bottom and were subsequently collected with the aid of a small probe and a dissecting microscope (Nikon SM-30). The identification of the parasites was based on the methodology of Kritsky et al. (1979). For the study of sclerotized structures, parasites were fixed in a solution of ammonium picrate glycerine (GAP) and mounted in Canada balsam. Some specimens were mounted 
unstained in Gray and Wess' medium. To visualize internal structures, parasites were fixed in hot formaldehyde solution (4\%) for staining with Gomori's trichrome. The parasitic indexes calculated for assessing the level of infestation of parasites in the fish were prevalence, mean intensity, abundance, and relative density (mean abundance) (Bush et al. 1997). The data were analyzed by ANOVA F statistic for analysis of variance with $5 \%$ significance, and the averages were compared by the Tukey's test. Differences were considered to be significant at $p<0.05$. The research was authorized by the Research Institute of the Peruvian Amazon, and necropsy of fish was conducted within the ethical standards.

\section{Results and discussion}

In the present study, the values of the physicochemical parameters of the water from the culture ponds were dissolved oxygen $\left(5.64 \pm 0.8 \mathrm{mg} \mathrm{L}^{-1}\right)$, $\mathrm{pH}(5.84 \pm 0.20)$, temperature $\left(28.23 \pm 0.9{ }^{\circ} \mathrm{C}\right)$, conductivity $\left(106.1 \pm 14.0 \mu \mathrm{s} \mathrm{cm}^{-1}\right)$, ammonium values $\left(0.05 \pm 0.10 \mathrm{mg} \mathrm{L}^{-1}\right)$, hardness $\left(21.40 \pm 1.80 \mathrm{mg} \mathrm{L}^{-1}\right)$, carbon dioxide $\left(3.2 \pm 0.9 \mathrm{mg} \mathrm{L}^{-1}\right)$, and total alkalinity $\left(16.14 \pm 0.80 \mathrm{mg} \mathrm{L}^{-1}\right)$. All water parameters remained within acceptable values for cultivated of tropical fish (Sipaúba-Tavares et al. 1994).

Parasitized fishes may present significant changes in their hematological and physiological characteristics, affecting their development (Ruane et al. 2000). Among the various groups of Helminthes that parasitize fishes from freshwater, the monogeneans, represented by many species, cause substantial economic losses in fish farms around the world (Scholz 1999). In the present study, from a total of 180 gamitana examined, 50 $(27.8 \%)$ were parasitized in the gills by monogenean Anacanthorus spathulatus and 130 (72.2\%) were free of parasites. The fish showed low level of parasitism and without apparent lesions. The Monogenoidea $A$. spatulatus was previously described by several authors parasitizing the gills of $C$. macropomum collected from natural environments and fish farms (Kritsky et al. 1979; Santos et al. 2013), confirming the occurrence of this parasite in C. macropomum, evidencing a high specificity of A. spatulatus parasitizing C. macropomum. However, this specificity may be related to the fact that many of monogeneans which parasitize fish are hostspecific, because of co-evolution with their hosts (Šimkovà et al. 2006). This is the first report of C. macropomum parasitized by A. spathulatus cultured in the Peruvian Amazon.

The evaluation of blood cells can be useful for the measurement of physiological disturbances in parasitized fish, and thus provide information about the level of damage in the host and the prognosis for the diseases (Tavares-Dias et al. 2007). According to Stosik et al. (2001), mechanisms of specific immunity in fish are significantly less developed and have a less important role than in other animals such as birds and mammals. However, fishes have non-specific resistance system, which plays the basic role in defense of the organism against pathogenic agents (Passantino et al. 2005), and blood leucocytes seem to represent an important defense line in these hosts. In parasitized fishes, the increase levels of circulating monocytes have been attributed to an improvement of cell defense system (Sopinska 1984). In the present study, there was no evidence of alteration in the leukocytes percentage. The results described herein are in accordance with Ranzani-Paiva et al. (1997) and Azevedo et al. (2006) who reported no changes in leukocytes distribution in Mugil platanus parasitized by monogenean, copepods, trypanosomes, and in Oreochromis niloticus parasitized by Trichodina sp., Lamproglena sp., and monogenean respectively. Furthermore, in a study with hybrid tambacu (Colossoma macropomum $\times$ Piaractus mesopotamicus) parasitized by several ectoparasites, Tavares-Dias et al. (2008) did not observe effect on leucocytes percentage. In the same manner, Martins et al. (2004) reported no significant alteration to leucocytes in Leporinus macrocephalus naturally infected by nematoda Goezia leporini. However, according to Tavares-Dias et al. (2008), it is difficult to comment on changes regarding the number of blood immune cells in parasitized fish, because the exact function of each cell is still little known.

According to the results, no significant alteration $(p>0.05)$ was observed in $\mathrm{RBC}, \mathrm{Hb}, \mathrm{Ht}, \mathrm{MCV}, \mathrm{MCH}$, MCHC, lymphocytes, and neutrophils (Table 1). Our results agree with the results published by Tavares-Dias et al. (1999) who reported no changes in RBC, Hb, Ht, MCV, MCH, and MCHC in P. mesopotamicus infected by Argulus sp. Azevedo et al. (2006) did not observe hematological alterations in $O$. niloticus parasitized with Trichodina sp., Lamproglena sp., and Cichlidogyrus sclerosus. In addition, Tavares-Dias et al. (2008) showed that the parasitism by Ichthyophthirius multifilis, Piscinoodinium pillulare and Lernaea cyprinacea in the hybrid tambacu did not provoke significant changes in the hematological variables. 
Table 1 Mean values \pm standard deviation of hematological parameters of $C$. macropomum ( $R B C$ red blood cell, $M C H C$ mean corpuscular hemoglobin concentration, $M C V$ mean corpuscular volume, $M C H$ mean corpuscular hemoglobin) non-parasitized and parasitized cultured in the Peruvian Amazon

\begin{tabular}{lcrr}
\hline Variables & Non-parasitized (130) & Parasitized (50) & Value $p$ \\
\hline Glucose $(\mathrm{mg} / \mathrm{dL})$ & $82.56 \pm 4.22 \mathrm{ab}$ & $118.43 \pm 0.12 \mathrm{~b}$ & 0.0163 \\
RBC $\left(\times 10^{6} / \mu \mathrm{L}\right)$ & $2.28 \pm 0.05 \mathrm{a}$ & $2.32 \pm 0.12 \mathrm{a}$ & 0.1086 \\
Hematocrit $(\%)$ & $29.17 \pm 4.22 \mathrm{a}$ & $30.68 \pm 5.14 \mathrm{a}$ & 0.6386 \\
Hemoglobin $(\mathrm{g} / \mathrm{dL})$ & $8.82 \pm 1.87 \mathrm{a}$ & $9.18 \pm 1.31 \mathrm{a}$ & 0.7891 \\
MCHC $(\mathrm{g} / \mathrm{dL})$ & $30.69 \pm 7.57 \mathrm{a}$ & $31.23 \pm 7.42 \mathrm{a}$ & 0.6378 \\
MCV $(\mathrm{fl})$ & $128.36 \pm 18.6 \mathrm{a}$ & $132 \pm 51 \pm 20.86 \mathrm{a}$ & 0.4641 \\
MCH $(\mathrm{pg})$ & $38.64 \pm 7.32 \mathrm{a}$ & $40.27 \pm 3.89 \mathrm{a}$ & 0.7549 \\
Leucocyte $(\mu \mathrm{l})$ & $2.45 \pm 0.31 \mathrm{a}$ & $2.43 \pm 0.21 \mathrm{a}$ & 0.5463 \\
Lymphocyte $(\%)$ & $25.6 \pm 7.5 \mathrm{a}$ & $26.4 \pm 5.2 \mathrm{a}$ & 0.8562 \\
Neutrophil $(\%)$ & $16.5 \pm 3.4 \mathrm{a}$ & $15.2 \pm 1.8 \mathrm{a}$ & 0.6947 \\
\hline
\end{tabular}

* Mean values in the same row sharing the same letter do not show significant differences $p>0.05$

The glucose in the plasma of the gamitana is mainly responsible for energy supply, but when glucose levels are high (hyperglycemia), it can be an important indicator in the production of hormones such as cortisol and adrenaline related to stress in fish captivity (Gustavenson et al. 1991). Cortisol administration to fish has been shown to reduce the number of circulating T- and B-like lymphocytes (Espelid et al. 1996). In the present study, it was observed increased $(p<0.05)$ glucose levels in $C$. macropomum parasitized when compared to non-parasitized fish (Table 1). Despite the increase in glucose levels in parasitized fish, it was not observed any physiological alteration in fish, since the rates of feed conversion ratio $(1.19 \pm 0.38$ ), weight gain $(81.20 \pm 3.22)$, and condition factor $(1.76 \pm 0.08)$ obtained are within the ranges for growing C. macropomum (Gomes et al. 2006). However, significant hyperglycemia was observed in the hybrid tambacu parasitized with Dolops carvalhoi (Tavares-Dias et al. 2007) and in Oncorhynchus mykiss infected by Lepeophtheirus salmonis (Ruane et al. 2000).

\section{Conclusion}

This study is the first report on hematological parameters in fish parasitized kept in captivity in the Peruvian Amazon. The low level of parasitism in C. macropomum was not sufficient to induce changes in the hematological parameters, and the low indexes of infestation by monogeneans confirmed the influence of good management of the fish ponds.

Acknowledgments Patrick Mathews Delgado in receipt of a fellowship from FAPESP, Brazil. Antonio F. Malheiros in receipt of a fellowship from CNPq, Brazil. The authors thank Dr. Omar Mertins for reviewing this manuscript.

Conflict of interest The authors declare that they have no competing interests.

Open Access This article is distributed under the terms of the Creative Commons Attribution License which permits any use, distribution, and reproduction in any medium, provided the original author(s) and the source are credited.

\section{References}

Alcántara FB, Chávez CV, Rodriguez LC, Kohler CC, Kohler ST, Camargo WC, Colace M, Tello S (2003) Gamitana (Colossoma macropomum) and paco (Piaractus brachypomus) cultured in floating cages in the Peruvian Amazon. World Aquac 34:22-24 Araujo-Lima CRM, Goulding M (1997) So fruitful fish: ecology, conservation, and aquaculture of the Amazon's tambaqui. Columbia University Press, New York, p 157

Azevedo TMP, Martins ML, Bozzo FR, Moraes FR (2006) Haematological and gills response in parasitized tilapia from valley of Tijucas river, SC, Brazil. Sci Agric 63:115-120 
Barton BA, Iwama GK (1991) Physiological changes in fish from stress in aquaculture with emphasis on the response and effects of corticosteroids. Annu Rev Fish Dis 10:3-26

Bush AO, Lafferty KD, Lotz JM, Shostak W (1997) Parasitology meets ecology on its own terms: Margolis et al. revisited. J Parasitol 83:575-583

Collier HB (1944) The standardization of blood haemoglobin determinations. Can Med Assoc J 50:550-552

Espelid S, Løkken GB, Steiro K, Bøgwald J (1996) Effects of cortisol and stress on the immune system in Atlantic salmon (Salmo salar L). Fish Shellfish Immunol 6:95-110

Goldenfarb PB, Bowyer FP, Hall E, Brosius E (1971) Reproducibility in the hematology laboratory: the microhematocrit determination. Am J Clin Path 56:35-39

Gomes LC, Chagas EC, Martins H, Roubach R, Ono EA, Lourenço JNP (2006) Cage cultured of tambaqui (Colossoma macropomum) in a central Amazon floodplain lake. Aquaculture 253:374-384

Gustavenson A, Widoski R, Wedemeyer G (1991) Physiological-response of largemouth bass to angling stress. Trans Am Fish Soc 120:29-36

Kritsky DC, Thatcher VE, Kayton RJ (1979) Neotropical Monogenoidea. The Anacanthorinae Price, 1967, with the proposal of four new species Anacanthorus Mizelle e Price, 1965 from Amazonian fishes. Acta Amaz 9:355-361

Martins ML, Tavares-Dias M, Fujimoto RY, Onaka EM, Nomura DT (2004) Haematological alterations of Leporinus macrocephalus (Osteichthyes: Anostomidae) naturally infected by Goezia leporini (Nematoda: Anisakidae) in fish pond. Arq Bras Med Vet Zootec 56:640-646

Mathews DP, Mathews DJP, Ismiño OR (2012) Massive infestation by Gussevia undulata (Platyhelminthes: Monogenea: Dactylogyridae) in fingerlings of Cichla monoculus cultured in the Peruvian Amazon. Neotrop Helminthol 6:231-237

Mathews DP, Mathews JPD, Ismiño RO (2013a) Parasitic infections in juveniles of Prochilodus nigricans ket in a semi-intensive fish farm in the Peruvian Amazon. Bull Eur Ass Fish Pathol 33:28-32

Mathews DP, Mertins O, Mathews JPD, Ismiño OR (2013b) Massive parasitism by Gussevia tucunarense (Platyhelminthes: Monogenea: Dactylogyridae) in fingerlings of bujurqui-tucunare cultured in the Peruvian Amazon. Acta Parasitol 58:223-225

Passantino L, Cianciotta A, Patruno R, Ribaud MR, Jirillo E, Passantino GF (2005) Do fish thombocytes play an immunological role? Their cytoenzimatic profiles and fuction during an accidental piscine candidiasis in aquarium. Immunopharmacol Immunotoxicol 27:345-356

Ranzani-Paiva MJT, Ishikawa CM, Campos BES, Eiras AC (1997) Haematological characteristics associated with parasitism in mullets, Mugil platanus Günther, from the estuarine region of Cananéia, São Paulo, Brazil. Rev Bras Zool 14:329-339

Rosenfeld G (1947) Dye pancrômico for hematology and clinical cytology. New combination of components of the MayGrünwald and Giemsa dye in one quick job. Mem Inst Butantan 20:329-334

Ruane NM, Nolan DT, Rotlant J, Costello EJ, Weendellar BSE (2000) Experimental exposure of rainbow trout Oncorhynchus mykiss (Walbaum) to the infective stages of the sea louse Lepeophtheirus salmonis (Kroyer) influences the physiological response to an acute stressor. Fish Shellfish Immunol 10:451-463

Santos GM, Santos ACM (2005) Amazon sustainability of fisheries. Estudos Avançados 19:165-182

Santos EF, Tavares-Dias M, Pinheiro DA, Neves LR, Marinho RGB, Dias MKR (2013) Parasitic fauna of tambaqui Colossoma macropomum (Characidae) farmed in cages in the State of Amapá, eastern Amazon. Acta Amaz 43:105-112

Scholz T (1999) Parasites in culture and feral fish. Vet Parasitol 84:317-335

Šimkovà A, Verneau O, Gelnar M, Morand S (2006) Specificity and specialization of congeneric monogenens parasitizing cyprinid fish. Evolution 60:1023-1037

Sipaúba-Tavares LH, Durigan JG, Ligeiro SR (1994) Characterization of some limnological variables in a nursery for fish farming in two periods of the day. Rev UNIMAR 16:217-227

Sopinska A (1984) Effects physiological factors, stress, and disease on hematological parameters of carp, with a particular reference to the leukocyte patterns. III. Changes in blood accompanying branchionecrosis and bothriocephalosis. Acta Ichthyol Piscat 15:141-165

Stosik H, Deptula W, Travnicek M (2001) Studies on the number and ingesting ability of thrombocytes in sick carps (Cyprinus carpio). Vet Med 46:12-16

Tavares-Dias M, Martins ML, Kronka SN (1999) Evaluation of the haematological parameters in Piaractus mesopotamicus Holmberg (Osteichthyes, Characidae) with Argulus sp. (Crustacea: Branchiura) infestation and treatment with organophosphate. Ver Bras Zool 16:553-555

Tavares-Dias MF, Ruas de Moraes EM, Onaka PC, Rezende B (2007) Changes in blood parameters of hybrid tambacu fish parasitized by Dolops carvalhoi (Crustacea, Branchiura), a fish louse. Vet Arh 77:355-363

Tavares-Dias M, Moraes FRL, Martins ML (2008) Hematological assessment in four brazilian teleost fish with parasitic infections, collected in feefishing from Franca, São Paulo, Brazil. Bol Inst Pesca 34:189-196

Wintrobe MM (1934) Variations on the size and hemoglobin content of erythrocytes in the blood various vertebrates. Folia Haematol 51:32-49 